\title{
Predicting internet addiction based on social skills \& mental security among university students
}

\author{
Fatemeh Raiisi ${ }^{1}$, Ameneh Hajikaram ${ }^{2}$, Fatemeh Bakhshi ${ }^{3}$, Maryam Tehrani Zadeh ${ }^{4}$, Fatemeh \\ Amani $^{5}$ \\ 1-PhD in Cognitive Science, Department of Psychology, Institute of Cognitive Science, Tehran, Iran (Corresponding \\ Author). E-mail: elhamaraiisi@gmail.com \\ 2- PhD in Counseling and Guidance, Department of Psychology, Abhar branch, Islamic Azad University, Abhar, \\ Iran. \\ 3- Master of General Psychology, Department of Psychology, Olom va Tahghghat Branch, Islamic Azad University, \\ Tehran, Iran. \\ 4- Assistant Professor, Department of Psychology, Karaj Branch, Payam-Noor University, Tehran, Iran. \\ 5- Master of General Psychology, Department of Psychology, Al- zahra University, Tehran, Iran.
}

Received: 21/01/2020

Accepted: 29/03/2020

\section{Abstract}

Introduction: Internet addiction among university students is affected by various psychological factors that include social skills and mental security.

Aim: The aim of this study was to determine the relationship between students' social skills and psychological security with internet addiction and also to predict internet addiction based on social skills and psychological security of Payam-Noor University students.

Method: The method of this study was descriptive- correlational. The population was all PayamNoor university students in Tehran who were students in 2019. The sample of this study included 250 university students who were selected through random cluster sampling. In addition to demographic questionnaire, Young internet addiction questionnaire (1996), Matson social skills questionnaire (1983) \& Maslow mental security (2004) were used. Descriptive statistics indices (mean and standard deviation) and multivariate regression analysis were used for data analysis by SPSS-22 software.

Results: The results indicated that there was a significant relationship between internet addiction with social skills \& mental security among university students $(\mathrm{P}<0.05)$. Moreover, 8.7\% of the variance in internet addiction was explained by social skills \& $2.3 \%$ of the variance in internet addiction was explained by mental security.

Conclusion: To conclude, it seems that the level of social skills and high psychological security has a positive and significant relationship with the reduction of internet addiction and it can predict reduction of internet addiction.

Keywords: Internet addiction, Social skills, Mental security, University students

How to cite this article : Raiisi F, Hajikaram A, Bakhshi F, Tehrani Zadeh M, Amani F. Predicting internet addiction based on social skills \& mental security among university students. Shenakht Journal of Psychology and Psychiatry. 2020; 7 (2): 128-139 .URL: http://shenakht.muk.ac.ir/article-1-931-fa.pdf

Copyright $\odot 2018$ the Author (s). Published by Kurdistan University of Medical Sciences. This is an open access article distributed under the terms of the Creative Commons Attribution-Non Commercial License 4.0 (CCBY-NC), where it is permissible to download, share, remix, transform, and buildup the work provided it is properly cited. The work cannot be used commercially without permission from the journal. 


\title{
يشبينى اعتياد به ايتترنت بر اساس مهارتهاى اجتماعى و امنيت روانى دانشجويان
}

\author{
فاطمه رئيسى'، آمنه حاجى كرم'، فاطمه بخشى '، مريم طهر انىزادهٌ، فاطمه امانى هـ \\ ا.دكتراى علوم شناختى، كروه روانشناسى ، موسسه آموزش عالى شناختى، تهران، ايران (مولف مسئول). ايميل: elhamaraiisi@ gmail.com

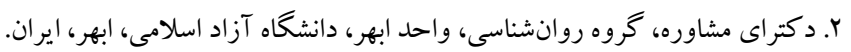

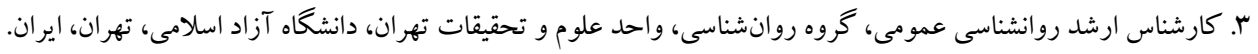

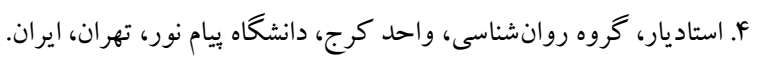

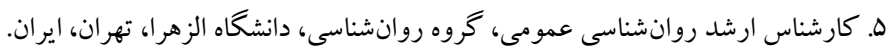

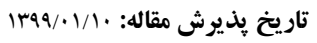

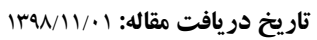

جكيده مقدمه: اعتياد به اينترنت در بين داشجويان تحت الشعاع عوامل روانشناختى گوناگونى است كه مىتوان از اين ميان به مهارتهاى اجتماعى و امنيت روانى اشاره كرد. هدف: يزوهش حاضر، با هدف تعيين رابطه بين مهارتهاى اجتماعى و امنيت روانى دانشجويان با اعتياد به اينترنت و همجنين،

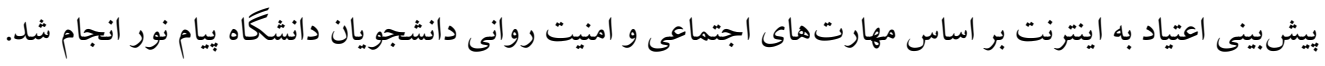

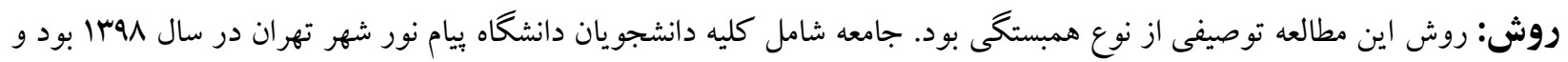

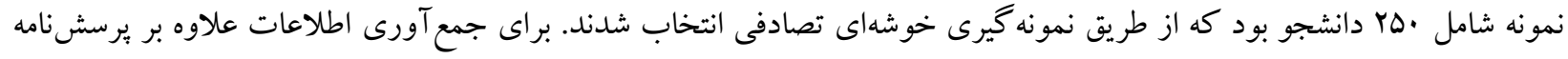

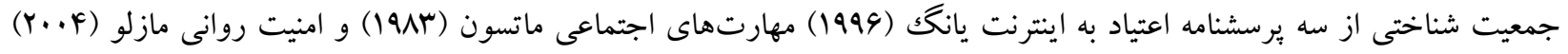

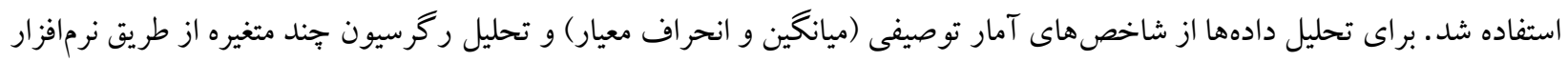
SPSS r r S استفاده شد. SPS

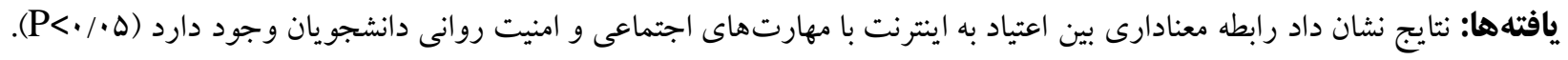
همجنين، N/V درصد از واريانس متغير اعتياد به اينترنت دانشجويان توسط مهارتهاى اجتماعى و م/Y درصد توسط امنيت روانى تبيين مى شود. نتيجه كيرى: بنابر اين، مى توان كفت ميزان مهارتهاى اجتماعى و امنيت روانى بالا با كاهش اعتياد به اينترنت رابطه مثبت و معنادارى دارد و كاهش ميزان اعتياد به اينترنت را يِيشبينى مئى كنند. كليدوازهها: اعتياد به اينترنت، مهارتهاى اجتماعى، امنيت روانى، دانشجويان 
در جوامع امروزى بسيار بيجيجيده شده است و انسانها براى مقدمه ايفاى نقش مؤثر و مفيد علاوه بر مهارتهاى اجتماعى به در دنياى امروز اعتياد به اينترنت' از جمله مشكلات رايج دانشها، نخرشها و مهارتهاى متفاوتى محتاج هستند كه عدم استفاده از آنها، باعث عدم ساز گارى و كيفيت

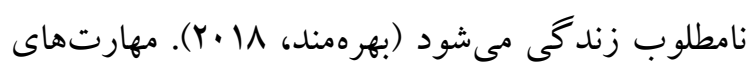

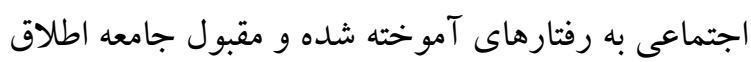
مىشوند؛ رفتارهايى كه شخص مى تواند به نحوى بـ با آن ارتباط متقابل برقرار سازد و منجر به بروز ياسخهاى منفى نشود. مؤلفهاى رفتارى مهارتهاى اجتماعى، توانايى تعامل سالم با ديخران، انعطافيذيرى و تطبيق خود با مهاي وضعيت محيطى و موقعيتى است (مرآتى و اسلام بناه، $(Y \cdot) r$

امنيت روانى " يكى از عوامل مهمى است كه بهواسطه آن

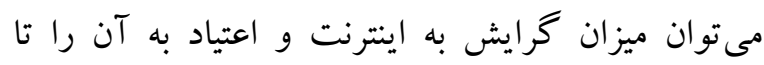
حدودى بيشبينى كند. در واقع، حالتى است كه در آن فرد اطمينان دارد از اينكه نيازها و خواستههاى شخصى اش تحقق مىيابند؛ بهعبارت ديخر، امنيت روانى يعنى آسايش خاطر ناشى از اطمينان شخص به بـ ارضاى بلى

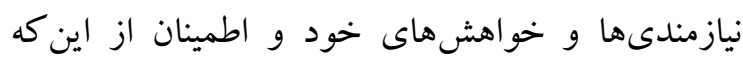
هيج كس او را تهايد نمى كند (دهقانى و ابراهيمى، و و. . . . احساس امنيت براى حفظ سلامت جسمى . روانى انسان لازم و ضرورى است. احساس عدم امنيت دائم شخص را در حالت بسيج قوا و بههمريختكى سوختو ساز بدن قرار مىدهد و اخر ادامه يابد، موجود را بهسوى بيمارىهاى جسمانى و روانى سوق خواهد داد. تأثيرى كه احساس نايمنى بر انسان دارد، ايجاد حالت تنش و برانگيختخى و عدم تعادل است. نخگ انى، ترس، وحشت و اضطراب، تنش و عصبانيت، جملكى از

\footnotetext{
4- Mental security
} و فراوان در بين نوجوانان و جوانان است و ساليانه خسارات جبراننايذيرى بر سلامتى آنها وارد مى كند. از طرفى، عوامل روانشناختى مختلفى بر روى ميزان

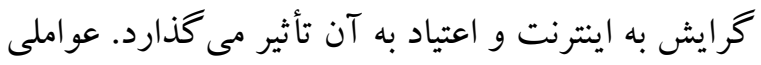
مانند متغيرهاى شخصيتى، انگيزشى، هيجانى، شناختى از جمله مهمترين آنهاست (اكبرى و فركت، 19 •.Y). استفاده بيمارگونه و افراطى از اينترنت و آسيبهاى اينترنتى تا به حدى است كه اكثر كشورها را بر آن واداشته تا با ايجاد و تأسيس كلينيككهاى تركى اعتياد به به به فن آورىها بهخصوص اينترنت، گامى مؤثر در بهبود

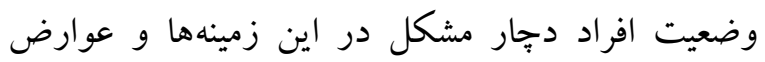
ناشى از آنها بردارند (بهرامى احسان، شاهواروقى و

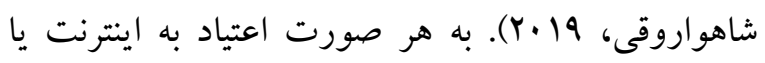
استفاده آسيبزا يا بيمارگ گنه از اينترنت يا كاربرى از آن است كه بر روى كاركرد فرد در زمينهاى مختلف زندگى اثر مخرب طولانى مدتى مى گذارد و رو روند زندگى عادى را مختل مى كند و بيامدهاى ناخوارى براى

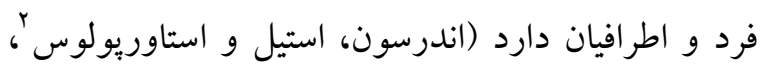
. (r. IV اكثراً افرادى كه مشكل در مهارت اجتماعى دارند براى رفع اين مسئله به استفاده مشكلزا از فضاى مجازى يناه مىبرند. مهارت هاى اجتماعى مهارتهايى هستند كه به افراد اجازه مىدهند تا تعاملات مثبى با ديخران شروع

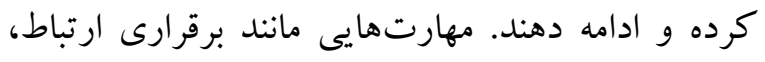
حل مسئله، تصميم گيرى، خود مديريتى، روابط با دوستان

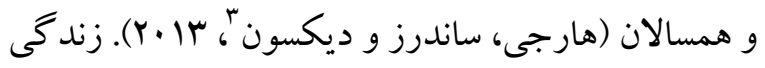

\footnotetext{
1- Internet addiction

2 - Anderson, Steen \& Stavropoulos

3 - Hargie, Saunders \& Dickson
} 
مهارتهاى اجتماعى و سلامت عمومى با اعتياد به اينترنت رابطه معنىدار و منفى وجود دارد. فياضى، رفاه و رفاهى (T/ · r) در ئزوهشى به اين يافته دست يافتند كه بين اعتياد به اينترنت با مهارت اجتماعى بيايين رابطه مستقيم و معنادار وجود دارد؛ اما با مهارت اجتماعى بالا

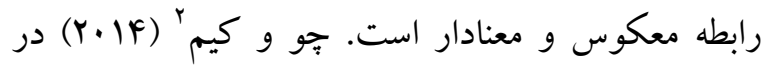
مطالعهاى علل گرايش به اعتياد را در بين دانشجويان بررسى كردند و نتايج آنها نشان داد كه عوامل روانشناختى مانند تنهايى و مهارتهاى اجتماعى با

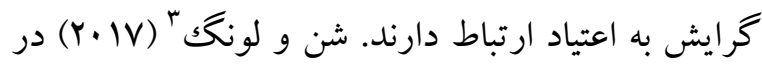
مطالعهاى علل روانشناختى گرايش به رفتارهاى اعتياد كونه بازىهاى مجازى را تنهايى، تمايل شديد به له له برانخيختكى، تمايل زياد به اعتياد و داشتن اوقات فراغت بهائ زياد يافنند. با توجه به اين كه امروزه، فناورىهاى نوين ارتباطى - مانى اطلاعاتى بهويزه اينترنت رشد و گسترش شخرفى در ابعاد

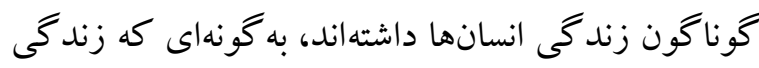
انسانها بيش از هر زمان ديخرى به اين دنياى مجازى وابسته گرديده و حتى بر اساس آن تحول جشمخيرى داشته است؛ بنابراين، اينترنت و سبك استفاده از آن به جزء لاينفك زندكى انسان تبديل شده است. از طرفى، اعتياد به اينترنت مقوله بيّيجيدهاى است كه با عوامل كوناگون روانشناختى و جامعهشناختى در ارتباط است. لذا مطالعه در اين حوزه، هميشه تازه و كوياى نياز بشر

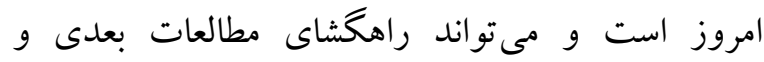
تخصصى و ايجاد راهكارهاى كاربردىتر باشد؛ بنابراين، اهميت اعتياد به اينترنت بر اين مبنا به عواملى مانند حس تنهايى، داشتن احساس امنيت روانى و مهارتهاى

${ }^{2}$ - Cho \& Kim

${ }^{3}$ - Chen \& Leung
بيامدهاى ناايمنى هستند. فردى كه نيازهاى ايمنى او ارضا شده باشد، همواره احساس دوستى و عشق، تعلق، آسودگى و راحتى، يذيرش خود و ديخران، عزت نفس، قدرت، دلكرمى، ثبات هيجانى، خوشنودى، علاقه اجتماعى، مهربانى، همدلى، فقدان تمايلات روان رنجورى و روانيريشى دارد (شولتز و شولتز '، 19.Y.). بر بايه بيزوهشهاى انجام شده، امنيت روانى و و مهارتهاى اجتماعى بهعنوان منبع مهمى از منابع مؤثر روانشناختى بر اعتياد به اينترنت افراد بهحساب مى آيند. بر اين اساس، يزوهشهاى مختلفى بر روى نمونهاى كوناگون انجام شده است. يعقوبى و زاهدى (19) دريافتند كه بين امنيت روانى و اعتياد به اينترنت در دانشجويان رابطهُ معنادار منفى وجود دارد و بر اساس اعتياد به اينترنت، امنيت روانى دانشجويان را مىتوان

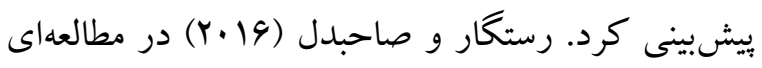
با هدف بررسى علل اعتياد نوجوانان و جوانان دريافتند

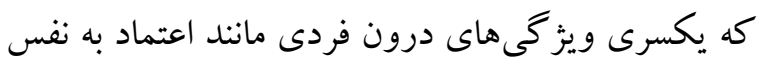
پايين، مهارتهاى ضعيف مقابلهاى و مهارتهاى اجتماعى ضعيف از علل گر ايش به اعتياد نوجوانان و جوانان مىباشند. يافته هاى مطالعه تاجيك اسماعيلى و اردكانيان (10 (Y) نشان داد كه دانش آموزان وابسته و غير وابسته به اينترنت از لحاظ مهارتهاى اجتماعى تفاوت معنادارى با هم دارند، يعنى مهارتهاى اجتماعى دانش آموزان غير وابسته بيشتر است. وهابى، وهابى، رجبى، تيفورى و احمديان (10 (Y) در تحقيقى يافتند كه بين اعتياد به اينترنت و مهارت اجتماعى دانشجويان رابطه وجود دارد. نتايج مطالعه احمدى، خديوى، حيدرى، احمدى، برهانى و خدامرادى (r|r. نشان داد كه بين

\footnotetext{
1- Schultz \& Schultz
} 
ذكر نام و رعايت اصول رازدارى يرسشنامهها توزيع شد. از هر دانشجو خواسته شد تا يرسشنامههاى مربوطه را كاملاً تكميل كرده و تحويل دهد. يُ از جمع آورى

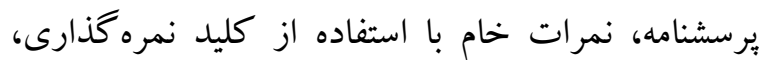
محاسبه گرديد. در اين يُزوهش، براى تحليل دادهها از آمارههاى توصيفى ميانكين، انحراف معيار و ضريب همبستخى بيرسون و در آمار استنباطى از تحليل ركرسيون

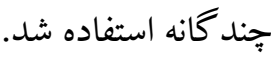

ابزار يرسشنامه جمعيت شناختى: كه شامل اطلاعاتى در مورد سن، جنس، وضعيت تأهل، مقطع تحصيلى و وضعيت

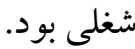

مقياس مهارتهاى اجتماعى': اين مقياس توسط ماتسون

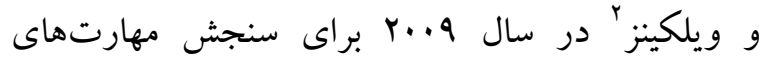
اجتماعى افراد \1 سال به بالا تدوين گرديده است. فرم اوليه اين مقياس داراى كو كويه بود كه توسط يوسفى و

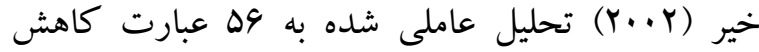
يافت. ياسخها بهصورت ه درجهاى از نوع ليكرت با دامنهاى از نمره ا (هر گز/ هيجوقت) تا ها (هميشه) مشخص مىشوند. ابعاد مقياس، عبارتاند از مهارتهاى

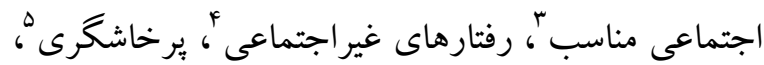

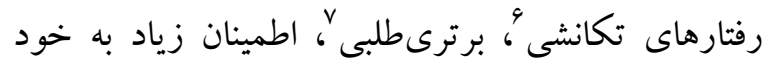

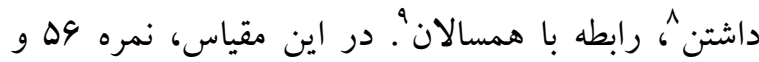
كمتر نشاندهنده مهارت اجتماعى كم و نمره

1. Social skills scale

2- Matson \& Wilkins

3 - Appropriate social skills

4- Non-social behaviors

5- Aggression

6- Impulsive behaviors

7- Superiority

${ }^{8}$ - Be very confident

${ }^{9}$ - Relationship with peers
اجتماعى بازمى گردد؛ بنابر اين، يزوهشخران اين مطالعه به

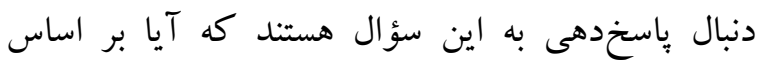
مهارتهاى اجتماعى و امنيت روانى دانشجويان مىتوان ميز ان اعتياد به اينترنت آنها را بيشيينى كرد؟

\section{روش}

روش بثزوهش حاضر توصيفى از نوع همبستگى است كه

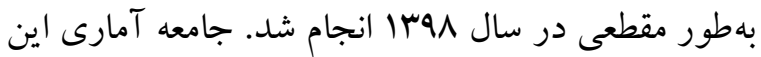
تحقيق شامل كليه دانشجويان دانشگاه بيام نور استان تهر ان بود. تعداد نمونه • •D دانشجو (بر اساس فرمول (هK+ جندمرحلهاى انتخاب شدند. بدين منظور بثزوهشگران از بين مراكز دانشگاهى بيام نور استان تهران سه مركز تهران غرب، تهران جنوب و تهران شرق را بهصورت تصادفى انتخاب كردند و به اين مراكز مراجعه كرده و بعد از

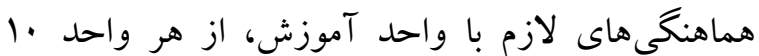
كلاس را (از مقاطع كارشناسى، كارشناسى ارشد و دكترا) بهصورت تصادفى انتخاب كردند. سيس از دانشجويان هر كلاس درخواست شد تا برسشنامهاى اين مطالعه را تكميل كنند.·rr برسشنامه به دليل مخدوش بودن و عدم همكارى دانشجويان كنار كذاشته شد. معيارهاى ورود به يثوهش، عبارت بودند از توانايى به اختيار گذاشتن اطلاعات و تجربيات خود، قرار داشتن بين سنين 1 1 تا هاله سال و دانشجو بودن. همجنين ملاكك خروج، عبارت بود از فارغالتحصيل يا كارمند بودن

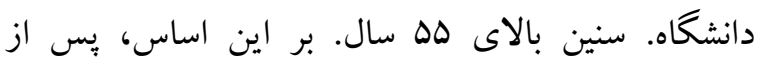

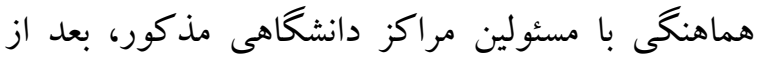
ايجاد ارتباط اوليه و همجنين ايجاد حس اعتماد نسبت به محرمانه بودن اطلاعات در بين دانشجويان و عدم نياز به 
قابل اجرا است. نياز به زمان كم، اجراى سريع با قدرت تشخيص بالا بين افراد روان رنجور و عادى از مزيتهاى اين آزمون است. نمره برش اين برسشنامه به گونهاى است

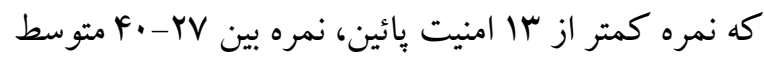
و نمره بين هF تا كF نمره بسيار بالايى است. در يزوهش شمس و خليجيان (r|r.|r) روايى برسشنامه ها با استناد به

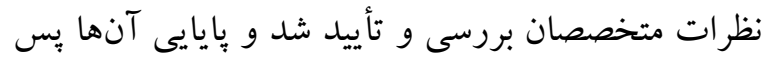

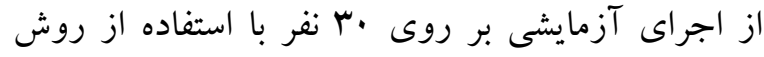

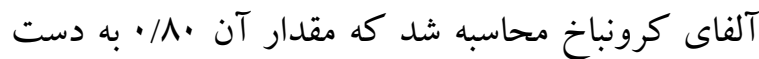
آمد.

r. برسشنامه اعتياد به /يتترنت يانتك ? اين برسشنامه شامل و Y F . اعتبار يابى شده است. طيف ياسخدهى آن بهصورت ليكرت بوده و داراى ينج درجه است. نمره به دست آمده

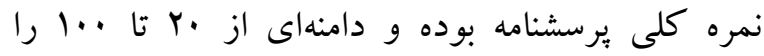
خواهد داشت. بديهى است كه هرجه اين نمره بالاتر باشد، بيانكر اعتياد بالاتر فرد به اينترنت خواهد بود. نمره برش اين يرسشنامه ·ه است. همجنين، اين وبرسشنامه

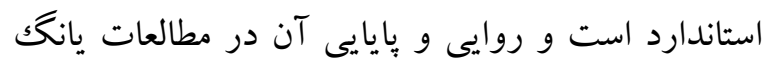
با آلفاى كرونباخ •9/ • گزارش شده است. نسخه فارسى اين مقياس در ايران نيز مورد استفاده قرار گرفته و و

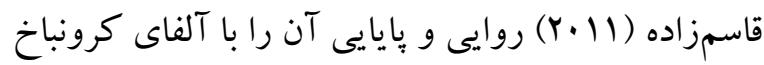

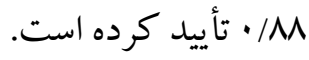

يافتهها براساس يافتهاى به دست آمده در خصوص توزيع نمرههاى جمعيت شناختى از . PD دانشجوى شركت

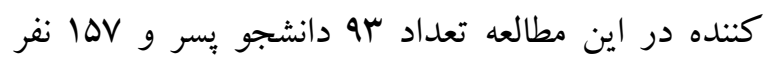

${ }^{6}$ - Young internet addiction questionnaire
نشاندهنده بيشترين مهارت اجتماعى است. در يخوهش يوسفى وخير (Y.+Y) روايى سازه اين يرسشنامه مورد تائيد قرار گرفت و ينج عامل به دست آمد و همجنين

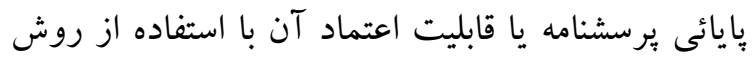
اندازه گيرى آلفاى كرونباخ محاسبه شد. آلفاى كرونباخ براى زيرمقياسها به ترتيب مهارتهاى اجتماعى مناسب

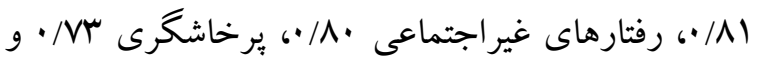
رفتارهاى تكانشى DD/•، برترىطلبى، اطمينان زياد به خود داشتن سA/•، رابطه با همسالان AV/· و براى كل مقياس 149/ • به دست آمد. برسشنامه /منيت روانى مازلو' (فرم كوتاه دانشجويی): اين اين يرسشنامه در سال F ... ت توسط مازلو بهمنظور سنجش امنيت روانى براى نوجوانان ها تا 19 ساله بر اساس مطالعات وسيع نظرى و بالينى در زمينه احساس ايمنى تهيه

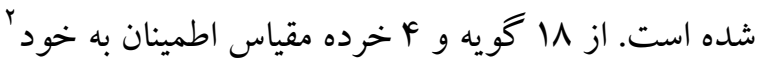
خود' (V سؤال)، احساس ناخشنودى ' (r سؤال)،

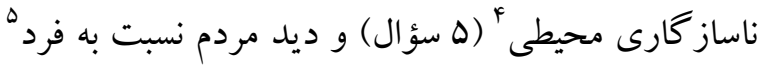
فرده (r سؤال) تشكيل شده است كه بهمنظور ارزيابى هـ امنيت روانى دانشجويان در دانشگاهها به كار مىرود. داراى السؤال دو گزينهاى با گزينهاى بلى و خير است و براى شناخت و سنجش آن دسته از خصوصيات فردى كه احساس ايمنى و ناايمنى را به وجود مى آورد و شناسايى افرادى كه نايمنى روانى و هيجانى دارند قابل استفاده است. از آن مىتوان بهمنظور تشخيص افرادى كه

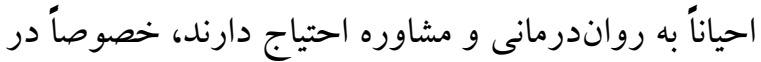
مواردى كه امكان مطالعه فردى وجود ندارد، استفاده كرد. معمولاً در V تا Y I جلسه بهصورت فردى و گروهى

\footnotetext{
- Maslow mental security questionnaire

2 - Self-confidence

3 - Dissatisfaction

4- Environmental maladjustment

5 - People's view of the individual
} 
همجنين براى يِيشينى اعتياد به اينترنت بر اساس

مهارتهاى اجتماعى و امنيت روانى دانشجويان از تحليل

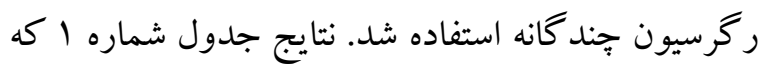
شامل شاخصهاى توصيفى از جمله ميانگين، انحراف معيار، شاخصهاى كجى و كشيدگى است.
دختر و در گروه سنى \ا تا هله سال قرار داشتند و

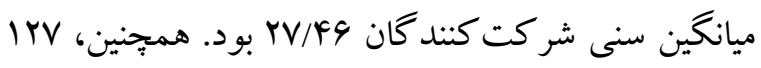
دانشجو در مقطع كارشناسى، Af دانشجو كارشناسى ارشد و هب دانشجوى دوره دكتراى تخصصى بودند. براى بررسى ميزان رابطه بين مهارتهاى اجتماعى و امنيت

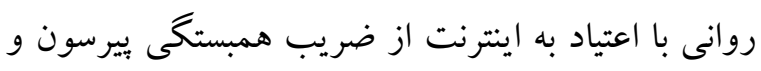

\begin{tabular}{|c|c|c|c|c|c|}
\hline كشيدكى & كجى & انحراف استاندارد & ميانغين & زير مؤلفه & متغير \\
\hline$-\cdot / \Delta \Delta$ & $\cdot / \Delta r$ & $\mid f / \cdot \Lambda$ & $90 / \cdot 9$ & مهارهاى مناسب & \\
\hline$\cdot / r \mid$ & $-\cdot / r$ & $\mid F / V \Lambda$ & $r Y / 10$ & رفتارهاى غير اجتماعى & \\
\hline$\cdot / F \Delta$ & $\cdot / \cdot r$ & $1 \% / \cdot$ & $\mathrm{rN} / \cdot 9$ & 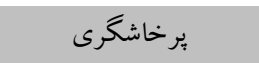 & \\
\hline$\cdot / r \Lambda$ & $-\cdot / \cdot \wedge$ & $F / r$ & IN/FY & رفتارهاى تكانشى & مهارت اجتماعى \\
\hline 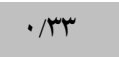 & $-\cdot / \mu r$ & $F / r$ & $r q / 4 i$ & برترىطلبى & \\
\hline .191 &.$- / 94$ & $r / r \Delta$ & $r M / \cdot \Lambda$ & رابطه با همسالان & \\
\hline 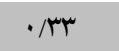 & $-\cdot / 4 q$ & $1 / 4 \lambda$ & $r F / \cdot r$ & اطمينان زياد به خود & \\
\hline$-\cdot / 4 \Delta$ & $\cdot /$ If & $1 / \cdot F$ & $1 / 94$ & احساس ناخشنودى & \\
\hline$-\cdot / V Y$ & $-\cdot / r \Delta$ & $1 / 1 r$ & $Y / Y F$ & اطمينان به خود & امنيت روانى \\
\hline$-\cdot / 4 q$ & $\cdot 199$ & $1 / 14$ & $F / 10$ & ن ناساز كارى & \\
\hline$-\cdot / \wedge \Delta$ & $\cdot / r \mid$ & $\cdot / \wedge 9$ & $1 / 4 \Lambda$ & ديد مردم نسبت به خود & \\
\hline$-\cdot \mid 91$ & $\cdot / 4 q$ & $r 1 / \cdot 9$ & $\Lambda r / Y r$ & - & اعتياد به اينترنت \\
\hline
\end{tabular}

اجتماعى، امنيت روانى با اعتياد به اينترنت از ضريب همبستخى بيرسون استفاده شد.
همانطور كه در جدول شماره ا مشاهده مىشود توزيع

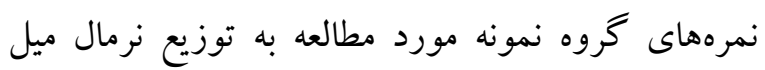
دارد. در جدول Y براى بررسى ميزان رابطه بين مهارت

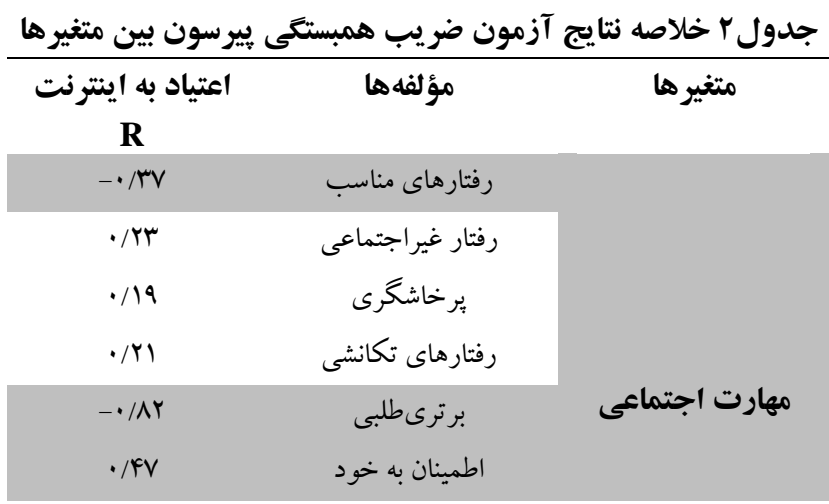




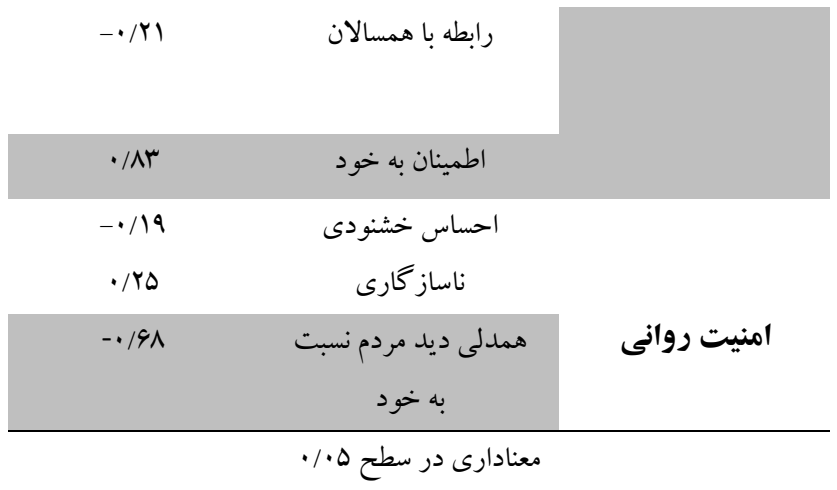

اجتماعى و امنيت روانى با اعتياد به اينترنت دانشجويان رابطه معنادار (ه•/•) مشاهده شد. همجِين در جدول r براى بيشبينى اعتياد به اينترنت بر اساس مهارتهاى اجتماعى و امنيت روانى دانشجويان از تحليل ركرسيون جند كانه استفاده شد.
ضرايب به دست آمده در جدول شماره Y بيانگر همبستكى بين متغيرهاى ييشبين و ملاكك است. جهت

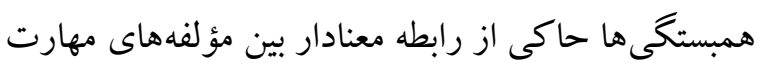
اجتماعى، امنيت روانى با اعتياد به اينترنت است؛ بنابراين،

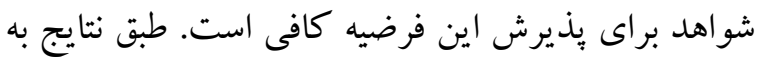

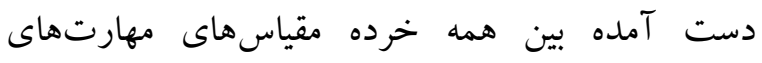

\begin{tabular}{|c|c|c|c|c|}
\hline سطح معنادارى & $\mathbf{T}$ & ضتغير وابسته: اعتياد به اينترنت استانداردشده & استاندارد نشده & ييشبينى كنندهها \\
\hline$\cdot / \cdots$ & $9 / \Delta 1$ & - & $9 / 01$ & عدد ثابت مهارت اجتماعى \\
\hline$\cdot \cdots$ & $-\Delta / \cdot r$ & $-\cdot / r r$ & .1 .9 & رفتارهاى مناسب \\
\hline.$/ 919$ & $\cdot / \cdot r$ &.$/ \cdot 1$ &.$/ 10$ & رفتار غيراجتماعى \\
\hline.$/ 991$ & $-\cdot / \cdot \cdot$ & $\cdot \cdots$ & .111 & يرخاشكرى \\
\hline$\cdot / v r$ & $\cdot / / 49$ &.$/ . \mathrm{ro}$ & $\cdot / r r$ & رفتارهاى تكانشى \\
\hline$\cdot / 4 F A$ & $-\cdot / V 4$ &.$- / .0$ &.$/ 19$ & برترىطلبى \\
\hline$\cdot / \Delta r \Lambda$ & $-1 / \cdot 9$ & $.1 .4 \Delta$ & $\cdot / r \mid$ & رابطه با همسالان \\
\hline$\cdot \cdots$ & $11 / 91$ & - & $r / \Delta \Lambda$ & عدد ثابت امنيت روانى \\
\hline.$/ .01$ & $-1 / N r$ &.$/ 11$ & .194 & اطمينان به خود \\
\hline .194 & $\cdot / \Delta F$ & . & $\cdot / \wedge 9$ & احساس ناخوشنودى \\
\hline$\cdot / M$ &.$/ \cdot \mu F$ & $\cdot / / F$ &.$/ 99$ & ناساز كارى \\
\hline • & $-1 / \Delta r$ & .1 .9 & $1 / 11$ & ديد مردم نسبت به خود \\
\hline
\end{tabular}

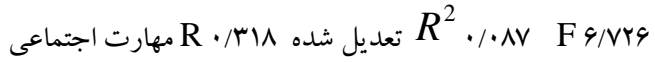

$$
\begin{aligned}
& \text { R: F:1/N1 } \\
& \text { ** معنادار در سطح I •/• • * معنادار در سطح ه•/. }
\end{aligned}
$$


اين مطالعه با هدف بررسى رابطه بين مهارتهاى اجتماعى و امنيت روانى دانشجويان با اعتياد به اينترنت و همجِنين، يِيشبينى اعتياد به اينترنت بر اساس مهارتهاى اجتماعى و امنيت روانى دانشجويان در دانشگاه بيام نور انجام شد. بر اين اساس نتايج نشان داد كه رابطه بين مهارتهاى اجتماعى و امنيت روانى دانشجويان با اعتياد به اينترنت رابطه معنادارى وجود دارد. آزمون اين فرضيه از طريق تحليل همبستگى انجام شد و نشان داد كه اين

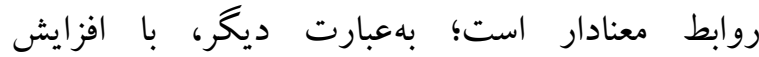
مهارتهاى اجتماعى و امنيت روانى، ميزان اعتياد به اينترنت كاهش مى يابد؛ بنابراين، شواهد براى بذيرش اين مفروضه كافى است. نتايج اين يزوهش با مطالعه يعقوبى و زاهدى (19) مبنى بر اين كه بين امنيت روانى و اعتياد به اينترنت در دانشجويان رابطهُ معنادار و منفى وجود دارد، با مطالعه وهابى و همكارانش (ها (Y) مبنى بر اين كه بين اعتياد به اينترنت و مهارت اجتماعى دانشجويان

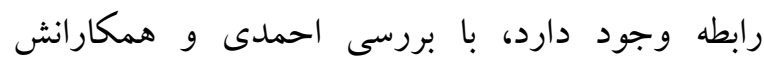

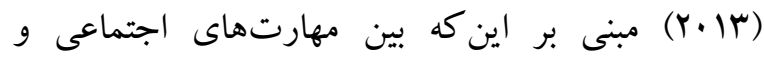
سلامت عمومى با اعتياد به اينترنت رابطه منفى وجود دارد و با مطالعه شن و لونگ (Y.IV) مبنى بر اين كه علل روانشناختى گرايش به رفتارهاى اعتيادگونه بازىهاى مجازى تنهايى، تمايل شديد به برانخيختخى، تمايل زياد به رفتارهاى عادت گونه و داشتن اوقات فراغت است، تقر يباً همخوان است. در تبيين اين فرضيه بايد گفت كه دانشجويان از اركان

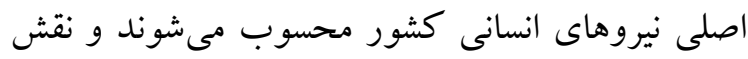

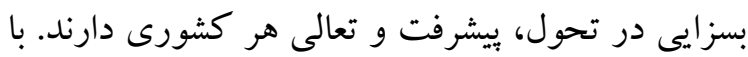
توجه به اهميت نقش دانشجويان در بيشرفت و تعالى هر جامعهاى، اين مسئله طبيعى است كه بررسى عوامل مؤثر
همانطور كه در جدول شماره ب مشاهده مىشود، مقدار

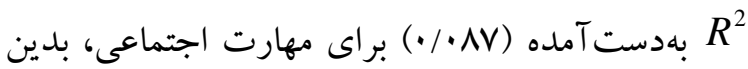
معنى است كه N/V درصد از واريانس متغير سطح اعتياد به اينترنت توسط متغير مهارتهاى اجتماعى تبيين مىشود؛ به عبارتديكر، N/V درصد از ير اكندگى مشاهده شده در متغير اعتياد به اينترنت توسط اين متغير توجيه مىشود. مقدار R مشاهده شده (N|N/^) نيز نشاندهنده آن است كه مدل ركرسيون خطى حاضر مىتواند براى بيشبينى استفاده شود. علاوه بر اين، نسبت F محاسبه شده (9/VY9) است. بنابراين، مىتوان نتيجه گرفت كه بين متغير مورد مطالعه و زيرمقياسهاى آن متغير اعتياد به اينترنت همبستگى معنادارى وجود دارد. هم:جنين، مقدار بهدست آمده براى امنيت روانى ( س •/•) بدين معنى است كه r/Y درصد از واريانس متغير سطح اعتياد به اينترنت توسط متغير امنيت روانى تبيين مىشود؛ بهعبارتديگر، r/r درصد از براكندگى مشاهده شده در متغير اعتياد به اينترنت توسط اين متغير توجيه مىشود. مقدار R مشاهده شده (9//) نيز نشاندهنده آن است كه مدل رگرسيون خطى حاضر مىتواند براى بيشبينى استفاده شود. علاوه بر اين، نسبت F محاسبه شده (1//1) در سطح اطمينان حداقل هو درصد معنادار است. بنابراين، مىتوان نتيجه كرفت كه بين متغيرهاى مورد مطالعه و متغير اعتياد به

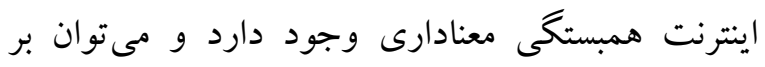
اساس اين متغيرها و مؤلفههايشان اعتياد به اينترنت را بيشبينى كرد. درنتيجه، شواهد براى بذيرش اين فرضيه ها

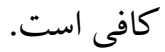


روانى، ميزان اعتياد به اينترنت دانشجويان قابل بيشبينى است؛ بنابراين؛ شواهد براى بذيرش اين فرضيه كافى است. نتايج اين يزوهش با مطالعه يعقوبى و زاهدى (Y.19) مبنى بر اين كه با استفاده از اعتياد به اينترنت

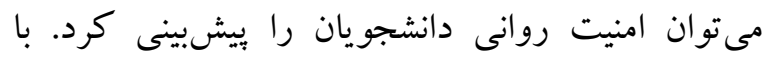
مطالعه فياضى و همكارانش (r|r.Y) مبنى بر اين كه بين

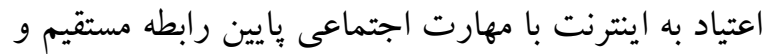

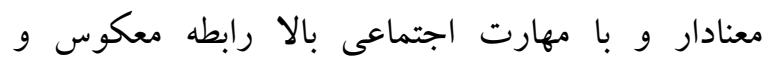

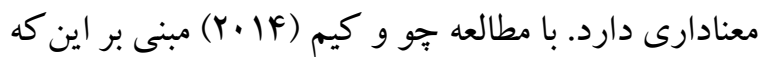
تنهايى و مهارتهاى اجتماعى مىتوانند بيشبينى كننده

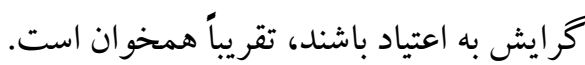
در تبيين اين فرضيه مىتوان گفت كه وابستخى رفتارى، ذهنى و روانى به اينترنت در افراد معتاد به اينترنت باعث مىشود تا ارتباطات رودررو، واقعى و خارج از فضاى

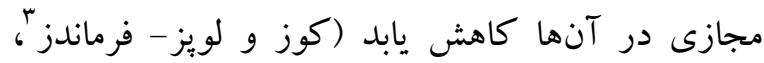
19 (Y). در اين ميان، ارتباط فرد با اطرافيان بهتدريج كم مىشود و فرد وابسته، بيشترين زمان خود را در اينترنت سيرى مى كند. ديخر نمىتوان از اين فرد انتظار برقرارى ارتباط اثربخش و همراه با مهارتهاى اجتماعى بالا داشت. اين وابستخى و اعتياد موجب مىشود در اين حالت، فرد به دنبال دست آويزى گردد كه از نظر روانشناختى به وى امنيت روانى بدهد (شكك و يو بُ، 19 (Y). از اينرو، فرد معتاد به فضاى مجازى هر روز به اينترنت وابسته از روز قبل گرديده و در ورطه يا دور معيوبى مىافتند كه همراه با كاهش بيشتر مهارتهاى اجتماعى و از دست دادن تدريجى احساس امنيت روانى است؛ بنابراين، فرد در عالم واقع، براى كسب آنجه از

${ }^{3}$ - Kuss \& Lopez-Fernandez

${ }^{4}$ - Shek \& Yu
در رشد ارضاى نيازهاى روانى و تأمين سلامت جسمانى و روانشناختى اين قشر از اهميت ويزهاى برخوردار باشد (ميرزائيان و باعزت، 4. ×.ب). از آنجايى كه استفاده از اينترنت ممكن است در دانشجويان باعث اعتياد به اين يديده شود و دانشجويان قشرى هستند كه اين آسيب آنها را به دلايل مختلف تهديد مى كند، مىتوان كفت كه اغلب دانشجويان معتاد به اينترنت مهارتهاى اجتماعى كمترى از خود نشان مىدهند؛ زيرا اين دانشجويان نسبت به ديخران، ساعتهاى زيادى غرق در فضاى مجازى و فضاهاى مختلف اينترنت هستند كه اين

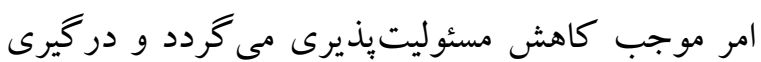
در اين فضا خود دليلى است بر كمبود مهارتهاى اجتماعى در دنياى واقعى كه اينگونه جبران مىشود

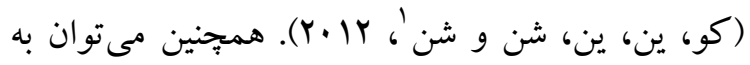

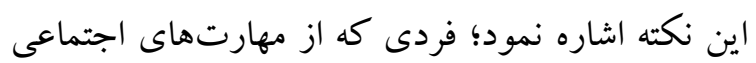
كمترى برخوردار است، باعث دور شدن ديخران از خويش مىشود و براى برقرارى ارتباط به دنياى مجازى

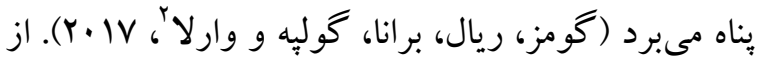
طرفى، فردى كه احساس امنيت در روابط مستقيم ندارد، تلاش مى كند تا اين روابط امن را در فضاى مجازى يا اينترنت بيايد؛ زيرا فضاى مجازى كمتر تهديد كننده است و قدرت ابراز وجود بهصورت جعلى در آن بيشتر است

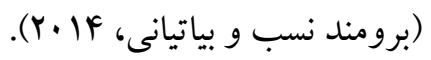
يافته ديخر اين مطالعه حاكى از اين موضوع است كه بر بروبل اساس مهارتهاى اجتماعى و امنيت روانى دانشجويان مىتوان ميزان اعتياد به اينترنت آنها را بيشبينى كرد. آزمون اين فرضيه از طريق تحليل رگرسيون جند نشان داد كه بر اساس مهارتهاى اجتماعى و امنيت

\footnotetext{
'- Ko, Yen, Yen, Chen, \& Chen

2- Gómez, Rial, Braña, Golpe, \& Varela
} 
with Internet addiction in the adolescents. Frooyesh, 8(9):157-164. (Persian)

Anderson EL, Steen E, \& Stavropoulos V. (2017). Internet use and problematic internet use: A systematic review of longitudinal research trends in adolescence and emergent adulthood. International joumal of adolescence and youth, 22 (4): 430-454.

Bahrami Ehsan H, Shahvaroghi A, \& Shahvaroghi MA. (2019). Relationship between intemet addiction and personality traits: a meta-analysis review. Frooyesh, 8 (4):213-224. (Persian)

Bahremand A. (2018). Investigating the relationship between social life skills and components of students' political education, case study. Master thesis, Shahid Bahonar university, Kerman. (Persian)

Borumand Nasab M, \& Bayatiani A. (2014). Relationship between social network size and loneliness, and general health in students of Islamic Azad University, Dezful. New research psychological issue. 3 (4): 12- 21. (Persian)

Chen C, \& Leung L. (2016). Are you addicted to Candy Crush Saga? An exploratory study linking psychological factors to mobile social game addiction. Telematics and informatics joumal, 33(4): 1155-1166.

Cho GY, \& Kim YH. (2014). Factors influencing SNS addiction among University students. Joumal of fisheries and marine sciences education, 26 ( 5): 1138-1150.

Dehghani H, \& Ebrahimi H. (2020). Studying the feeling of social and psychological Security with a tendency toward superstition; case study: Isfahan university students. Strategic research on social problems joumal in Iran, 8(27): 99-122. (Persian)

Fayazi R, Refah Zh, \& Refahi, N. (2013). Social Skills and Demographic Characteristics: Intemet Addiction Predictor. National congress of child and adolescent psychology. Tehran, Iran. (Persian)

Gómez P, Rial A, Braña T, Golpe S, \& Varela J. (2017). Screening of problematic intemet use among Spanish adolescents: prevalence and

$$
\begin{aligned}
& \text { دست داده به استفاده روزافزون و بيمارگونه از اينترنت يا }
\end{aligned}
$$

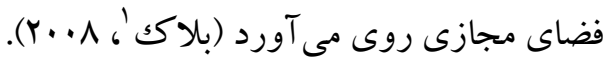

$$
\begin{aligned}
& \text { نتيجه كيرى } \\
& \text { بهطور خلاصه، يافتهاى يزوهش حاضر نشان داد كه } \\
& \text { ميزان اعتياد به اينترنت دانشجويان با مهارت هاى اجتماعى } \\
& \text { و امنيت روانى آنها ارتباط دارد و مىتوان بر اساس } \\
& \text { مهارتهاى اجتماعى و امنيت روانى ميزان اعتياد به } \\
& \text { اينترنت آنها را بيشبينى كرد. يُزوهش حاضر داراى } \\
& \text { محدوديتهايى بوده و يثزوهشخران را با مشكلاتى مواجه } \\
& \text { كرده است. ازجمله: مقطعى بودن نوع مطالعه، عدم كنترل } \\
& \text { متغيرهاى تعديل گر و دانشجو بودن نمونه مورد مطالعه. در } \\
& \text { ضمن، يافته هاى اين مطالعه نتايج مطالعات كذشته را } \\
& \text { توسعه داده است؛ بنابراين، به محققان براى بزٔوهشها در } \\
& \text { آينده بيشنهاد مى شود تا در اين زمينه مطالعاتى بر روى }
\end{aligned}
$$

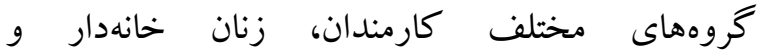

$$
\begin{aligned}
& \text { دانش آموزان انجام دهند. } \\
& \text { سياسگزارى } \\
& \text { از دانشجويان ييام نور واحدهاى تهران غرب، تهران } \\
& \text { جنوب و تهران شرق كه در اين مطالعه ما را يارى كردند، } \\
& \text { كمال تشكر و قدردانى را داريم. }
\end{aligned}
$$

\section{References}

Ahmadi V, Khadivi M, Heidary M, Ahmadi S. Borhani L, \& Khoda Moradi M. (2013). Social skills, general health \& internet addiction in university students. Contemporary Psychology, 7(1), 90-94. (Persian)

Akbari B, \& Forget A. (2019). The relationship between self-awareness and personality traits

\footnotetext{
1. Block
} 
related variables. Cyber-psychology, behavior, and social networking joumal, 20 (4): 259-267.

Hargie O, Saunders k, \& Dickson D. (2013). Social skills in interpersonal communication. the University of Michigan; Croom Helm.

Ko CH, Yen JY, Yen CF, Chen CS, \& Chen CC. (2012). The association between intemet addiction and psychiatric disorder. a review of the literature. European psychiatry joumal, 27 (1):1-8.

Kuss D, \& Lopez-Femandez O. (2016). Intemet-use related addiction: the state of the art of clinical research. European psychiatry joumal, 33: 303-312.

Matson JL, \& Wilkins J. (2009). Psychometric testing methods for children's social skills. Research in Developmental Disabilities, 30: 249-274.

Merati AR, \& Islam Panah M. (2012). Investigating the relationship between Intemet addiction and students' social skills. Quarterly social psychology research, 2(8): 145-156. (Persian)

Mirzaeean B, \& Baezzat F. (2006). Internet addiction among students and its impact on mental health. Joumal of information and communication technologies in education, 3(4): 185-206. (Persian)

Rastegar MA, \& Sahebdel H. (2016). Investigating the causes of drug addiction among adolescents and young people and ways to prevent it. Third national conference on strategies for the development and promotion of educational sciences, psychology, counseling and education in Iran. (Persian)

Schultz D, \& Schultz SE. (2016). Theories of personality. 11th edition. United States, Cengage learning.

Shek TL, \& Yu Lu. (2016). Adolescent intemet addiction in Hong Kong: prevalence, change, and comrelates. Joumal of pediatric and adolescent gynecology, 29 (1): S22-S30.

Tajik Esmaeili S, \& Ardekanian R. (2015). Examining the impact of intemet addiction on students' social skills in smart and regular schools. QJFR, 12 (2):7-26. (Persian)
Vahabi A, Vahabi B, Rajabi N, Tafuri S, \& Ahmadian M. (2015). An evaluation of intemet addiction $\&$ its related factors among the students of Kurdistan university of medical science in 2015. Quarterly joumal of medical education development. 8 (19): 99-111. (Persian)

Yaghoubi A, \& Zahedi F. (2016). An analysis of the mediating role of homesickness in the relationship between internet addiction and psychological security of the students of the Islamic azad university of Hamedan. Hamedan law enforcement knowledge joumal. 3(4): 113-147.(Persian)

Young KS. (1996). Intemet addiction: The emergence of a new clinical disorder. Cyber psychology and behavior,1(3): 237-244. 